\title{
$\frac{100}{\text { LAT }}$ RPEiS
}

\section{„DZIEDZICZENIE” RODZINNYCH OGRODÓW DZIAŁKOWYCH. UWAGI DE LEGE LATA I DE LEGE FERENDA}

\section{RENESANS PRAWA SPADKOWEGO W POLSCE}

$\mathrm{Na}$ świecie prawo spadkowe swe najlepsze lata ma już za sobą. Co najmniej od połowy XX w. to nie ono odpowiedzialne jest za sukcesyjny przepływ majątku w społeczeństwie i w gospodarce. Rolę tę przejęło prawo gospodarcze. Obecnie właścicielami coraz większej części globalnego majątku są podmioty gospodarujące (rozmaite spółki, fundacje itd.). Śmierć nie ma tu już funkcji „regulatora przepływu”. Stosownie do tego znaczenie prawa spadkowego zmalało, historyczne zaś uzasadnienie wielu jego instytucji odwołujace się do ochrony porządku demokratycznego (przez „wymuszanie” rozproszenia majątku i przeciwdziałanie jego nadmiernej koncentracji, a więc zapobieganie tworzeniu się fortun zagrażajacych demokracji ${ }^{1}$ ), wydaje się dzisiaj nie tylko archaiczne i śmieszne, ale nawet w ogóle niezrozumiałe.

W Europie, wobec daleko skromniejszej obecnie roli prawa sukcesyjnego, budzi ono odpowiednio mniejsze zainteresowanie. Gdy dodatkowo zważyć na to, że instytucje prawa spadkowego były już w końcu XIX w. dobrze skrojone i dopasowane do potrzeb społeczeństwa zbudowanego na poszanowaniu własności, nie może dziwić, że wiele w zachodnioeuropejskim prawie spadkowym dzisiaj się nie dzieje.

* Tomasz Justyński, Uniwersytet Mikołaja Kopernika w Toruniu, tomjust@uni.torun.pl, https://orcid.org/0000-0003-0270-4178

1 Tak uzasadniano jeszcze w niemieckim Kodeksie cywilnym (BGB) z 1896 r. (RGBl. S. 195; BGBl. III 400-2) np. instytucję „dziedziczenia przymusowego”, czyli zachowku (niem.: Pflichtteil). Analogiczna myśl towarzyszyła wcześniej Napoleonowi, który w „przymusie podziału majątku spadkowego" dostrzegał instrument rozbicia dawnej władzy i jej feudalnego stanu posiadania (,starej” arystokracji). Por. Bucholz (2007): 120. W polskiej literaturze zob. Justyński (2018a): $338 \mathrm{n}$. 
Inaczej jest w Polsce. Tu mamy do czynienia z prawdziwym renesansem prawa spadkowego. Nie chodzi wprawdzie o to, żeby miało ono ciagle jeszcze pełnić rolę „dystrybutora” albo „regulatora przepływu” majątku, a tym samym chronić demokrację. Tak oczywiście nie jest. W Polsce nadrabiane są kilkudziesięcioletnie zaległości z czasów tzw. realnego socjalizmu, czyli z okresu kompletnej niemal hibernacji prawa i praktyki prawnospadkowej. Przywracane są (niestety nie dość sprawnie), celowo usunięte w czasach PRL, tradycyjne instytucje prawa spadkowego. Szczególnie te z obszaru tzw. prawa testamentowego, umożliwiającego właścicielowi (spadkodawcy) zadysponowanie majątkiem w sposób rzeczywiście zgodny z jego wolą. Te właśnie możliwości - jak wiadomo - nie zawsze podobały się ,prawodawcy socjalistycznemu”, co było przyczyną eliminacji wielu ważnych i w praktyce przydatnych konstrukcji prawnych z Kodeksu cywilnego z $1964 \mathrm{r}$.

O renesansie prawa spadkowego w Polsce świadczy jednak przede wszystkim to, że na wokandach sądów powszechnych gości coraz więcej spraw spadkowych. Oczywiście nie bez powodu. Pojawiają się coraz bardziej znaczące majątki, rośnie więc zarówno zainteresowanie dobrze skrojonymi zasadami dziedziczenia ustawowego, jak i zapotrzebowanie na możliwie swobodne dysponowanie nimi mortis causa $\mathrm{w}$ drodze testamentowej. W konsekwencji rośnie także liczba sporów prawnych na tym tle.

Sprawy te coraz częściej trafiają także przed oblicze Sądu Najwyższego. Wobec nienadążania prawodawcy za potrzebami w tym zakresie, Sąd Najwyższy nierzadko stawiany jest przed bardzo trudnym zadaniem. Zmuszony jest mianowicie osiaggać w drodze wykładni prawa to, co do osiągnięcia możliwe. Nie zawsze udaje się to wystarczająco dobrze ${ }^{2}$.

\section{PROBLEM Z „DZIEDZICZENIEM” RODZINNEGO OGRÓDKA DZIAŁKOWEGO}

Ostatnimi czasy Sąd Najwyższy, a przed nim kilka sądów powszechnych, skonfrontowany został z niezwykle ciekawym, a przy tym bardzo złożonym jurydycznie problemem „dziedziczenia” rodzinnych ogródków działkowych.

2 Zob. np. nieudana próba przesądzenia dopuszczalności darowizny mortis causa (wyrok z 13 grudnia 2013 r., III CZP 79/13, OSNC 2014, nr 10, poz. 98 z glosą Justyńskiego (2014): 91 n.; Księżaka (2015): 123, czy także chybione propozycje w zakresie terminu do złożenia oświadczenia o przyjęciu bądź odrzuceniu spadku w imieniu dziecka (zob. uchwała SN z 22 maja 2018 r., III CZP 102/17 z glosą Justyńskiego (2020b); uchwała SN z 15 lutego 2019 r., III CZP 85/18, www. Sn.pl, Legalis nr 1874715 z glosą Justyńskiego (2019b); zob. też uchwała SN z 15 marca 2018 r., III CZP 110/17 z glosa Justyńskiego (2019c); postanowienie SN z 12 kwietnia 2018 r., II CSK 485/17 z glosą Justyńskiego (2020a); nietrafne dopuszczenie w drodze wykładni zapis u alter na ty w ne go (uchwała SN z 16. października 2014 r., III CZP 70/14 z glosą Justyńskiego (2015); Księżaka (2016), próba dopuszczenia de lege lata zrzeczenia się prawa do zachowku (uchwała SN z 17. marca 2017 r., III CZP 110/16 z glosą Jasiakiewicza (2018); Justyńskiego (2018b). Przy tym, obok tych nietrafnych, ale wnoszących sporo do dyskusji, było też wiele przykładów ważnych i trafnych rozstrzygnięć. 
Jak wiadomo, ciagle jeszcze istotnym składnikiem majątku wielu osób, głównie starszego pokolenia, sa - modne i propagowane w czasach PRL (także z powodu ogólnej mizerii gospodarczej) - rodzinne ogródki działkowe. Nierzadko wraz z poczynionymi na nich inwestycjami (tj. nasadzeniami roślinnymi, zainstalowanymi rozmaitymi urządzeniami i wzniesionymi obiektami) maja one sporą wartość.

Okazuje się, że na tle tego składnika majątku powstaje istotny problem spadkowy, zarówno natury teoretycznej, jak i w szczególności dużej praktycznej doniosłości. Chodzi mianowicie o odpowiedź na dwa fundamentalne, a w dalszej kolejności przynajmniej kilka bardziej szczegółowych, pytań. Po pierwsze, czy działka (wraz z nasadzeniami urządzeniami i obiektami) wchodzi do masy spadku? A więc, czy jest dziedziczona na zasadach ogólnych, tak jak każdy inny składnik majątku? Po drugie zaś, czy rodzinny ogródek działkowy powiększa podstawę naliczenia zachowku (czyli tzw. substrat zachowku) dla osób uprawnionych?

Prima facie rzecz, wydawałoby się, nie powinna budzić wątpliwości. Przecież już w 2005 r. (w nowych realiach społecznych, gospodarczych oraz politycznych) prawodawca uregulował problematykę w ustawie o rodzinnych ogrodach działkowych ${ }^{3}$, w 2013 r. zaś zastapił ją nowa, kompleksową ustawa dość gruntownie porządkująca problematykę) ). Okazuje się jednak, że daleko nie wszystkie wątpliwości - szczególnie te prawnospadkowe - zostały w ten sposób skutecznie przecięte.

O ile odpowiedź na pierwsze z postawionych pytań nie sprawia większych, czy w szczególności nieprzezwyciężalnych, kłopotów interpretacyjnych (zagadnienie, jak się wydaje, zostało stosunkowo jasno, nawet jeśli nie wprost, przesądzone w ustawie), o tyle drugie pytanie i odpowiedź na nie stanowi już prawdziwe wyzwanie ${ }^{5}$.

Warto zatem przyjrzeć się bliżej zagadnieniu dziedziczenia rodzinnych ogródków działkowych i dalszym wynikającym z niego konsekwencjom prawnospadkowym.

Dobrego punktu wyjścia do rozważenia tych kwestii dostarcza orzeczenie

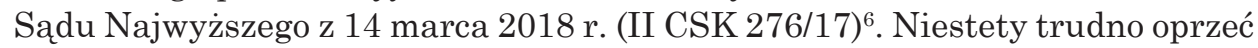
się wrażeniu, że orzekając w sprawie, SN nie wykorzystał szansy generalnego przesądzenia problemu, z którym od dość dawna borykają się sądy powszechne, a w konsekwencji szansy ujednolicenia praktyki w skali kraju.

\section{BATALIA O DZIAŁKĘ PRZED SĄDEM NAJWYŻSZYM}

Przed przystapieniem do naświetlenia kwestii teoretycznoprawnych warto pokrótce zrekonstruować ciekawy, a jednocześnie modelowo-typowy stan

\footnotetext{
${ }^{3}$ Ustawa z 8 lipca 2005 r., Dz. U. Nr 169, poz. 1419.

${ }^{4}$ Ustawa o rodzinnych ogrodach działkowych z 13 grudnia 2013 r., t.jedn.: Dz. U. 2017, poz. 2176.

${ }^{5}$ Zob. na ten temat Justyński (2020c): D3.

${ }^{6}$ Legalis nr 1835926, z glosą Justyńskiego (2020d).
} 
faktyczny sprawy rozstrzyganej przez Sąd Najwyższy. Pozwoli to na lepsze ulokowanie generalnej problematyki prawnospadkowej.

Otóż, rzecz dotyczyła zachowku dla syna po zmarłej (w roku 2009) spadkodawczyni. Ta pominęła go bowiem przy dziedziczeniu, pozostawiając cały swój majątek jedynej wnuczce, będącej córką pominiętego. Dla syna przewidziała wyłącznie prawo dożywotniego zamieszkiwania w mieszkaniu. W tej sytuacji pominięty zażądał od córki (będącej spadkobierczynią testamentowa) należnego mu zachowku.

Wartość spadku była niebagatelna. Sąd określił ją na prawie 400000 zł (na co składały się m.in.: mieszkanie o wartości blisko 250000 zł oraz ogródek działkowy z altana, nasadzeniami i innymi urządzeniami wart blisko 100000 zł). Stąd należny zachowek Sąd wyliczył na prawie 200000 zł, co stanowiło 1/2 tego, co przypadłoby uprawnionemu przy dziedziczeniu ustawowym.

Ponieważ syn zmarłej uzyskał jednak prawo dożywotniego korzystania z mieszkania, wartość tego prawa została zaliczona na poczet należnego zachowku. Pozostała część (w kwocie 88000 zł) wywołała prawdziwe zamieszanie. Chodziło o to, że Zarząd Ogrodów Działkowych po śmierci działkowca (spadkodawczyni) przydzielił działkę odsuniętemu od dziedziczenia synowi, nie zaś będącej spadkobierczynią wnuczce. Oczywiście, co zresztą w sprawie nie budziło wattpliwości, miał do tego prawo (art. 31 ust. 4 ustawy z 2005 r.). Decyzja o przyznaniu działki jednemu spośród kilku ubiegających się o przydział krewnych należała, w tamtych realiach prawnych, właśnie do Zarządu Ogrodów. Jeśli Zarząd postapiłby odwrotnie, sprawy nie byłoby.

W powstałej sytuacji Sąd doszedł do wniosku, że domaganie się przez syna zachowku w pełnej wysokości jest nadużyciem prawa (art. 5 k.c.). Dlatego też obniżył go właśnie o 88000 zł, uzasadniając, że uprawniony kwotę tę już otrzymał pod postacią przydziału działki.

Prima facie rozstrzygnięcie takie może wydawać się słuszne i sprawiedliwe. W ten sposób udało się przecież zapobiec sytuacji, w której syn niejako „podwójnie” uzyskuje swój zachowek (a przynajmniej jego istotną część). Nie można bowiem nie dostrzegać tego, że wartość ogródka (razem z altana, nasadzeniami i urządzeniami) zwiększyła, z jednej strony, podstawę obliczenia należnego zachowku, z drugiej zaś - stała się, w wyniku przydziału, wyłącznie jego prawem.

Wbrew pozorom sięganie do konstrukcji nadużycia prawa nie było ani potrzebne, ani - w szczególności - poprawne konstrukcyjnie ${ }^{7}$.

Po pierwsze, chodzi o to, że zastosowanie art. 5 k.c. do oceny żądania zachowku jest wprawdzie, co do zasady, dopuszczalne, czego nikt nie neguje, jednakże nie może prowadzić do definitywnej utraty (w całości lub w części) prawa domagania się zachowku ${ }^{8}$. Już z tego powodu odwołanie się do nadużycia prawa w okolicznościach sprawy nie tylko nie było dopuszczalne, ale też nie mogło niczego „raz na zawsze” (definitywnie) rozwiązywać.

7 Szeroko na temat tego orzeczenia w glosie przywołanej w przyp. 6.

$8 \mathrm{Na}$ temat zasad stosowania art. 5 k.c. zob. Justyński (2000). Por. też Justyński (2017); Jasiakiewicz (2017); Księżak (2010): 357 n. Zob. też. Pyziak-Szafnicka (2007): 807 n. 
Po drugie, a raczej nawet: przede wszystkim, kierunek wskazany przez Sąd nie jest właściwy dlatego, że SN nie przydał znaczenia odrębnym regułom sukcesji rodzinnych ogrodów działkowych, a w szczególności nie wyprowadził z nich konsekwentnie wniosków w zakresie zachowku. A przecież to właśnie ta kwestia, nie zaś ewentualne nadużycie prawa, ma w sprawie dziedziczenia ogródków działkowych podstawowe i decydujące znaczenie. Ona też zasługuje na szczególną uwagę i będzie przedmiotem dalszych rozważań.

\section{CHARAKTER PRAWNY PRAWA DO RODZINNEGO OGRODU DZIAŁKOWEGO}

Na prawo do działki składają się dwa komponenty o zasadniczo odmiennym charakterze. Z jednej strony chodzi o prawo do samego gruntu, z drugiej zaś - o odrębne od niego uprawnienie do poczynionych przez działkowca nasadzeń roślinnych oraz wzniesionych altan i innych urządzeń.

Jedno, to pierwsze, jest słabsze i ma charakter obligacyjny. Działkowiec nie jest więc ani właścicielem działki, ani nawet jej prawnorzeczowym użytkownikiem. Jest jedynie jej dzierżawca. Na tle ustawy z 2005 r. można było mieć w tym zakresie wątpliwości. Prawodawca nazywał bowiem prawo działkowca „prawem używania działki i pobierania z niej pożytków” (tak w art. 14 ust. 1), a nawet wprost „użytkowaniem działki” (art. 14 ust. 1 i 2), do tego wszystkiego dodał, że „w rozumieniu Kodeksu cywilnego” (art. 14 ust. 2). Musiało to rodzić oczywiste skojarzenia z prawnorzeczowym, skutecznym erga omnes (ale jednak niedziedzicznym) prawem użytkowania. Nawet jednak wówczas sformułowania pozostałych przepisów ustawy zasiewały wątpliwości przynajmniej co do tego, czy jest tak w każdym przypadku i czy czasami nie chodzi jednak o prawo obligacyjnej natury, układajace się w płaszczyźnie umowy dzierżawy ${ }^{9}$. Ustawa z 2013 r. na wątpliwości takie nie pozostawia już miejsca. Prawodawca nie tylko nazwał (w art. 27 ust. 1 ustawy), ale też wprost odesłał do umowy dzierżawy uregulowanej w Kodeksie cywilnym (art. 28 ust. 5 ustawy).

Drugie prawo jest w tym kontekście zaskakująco silne. Chodzi mianowicie o prawo własności (dominium) połączonych z działką elementów (nasadzeń, altan i innych urządzeń), których własność wbrew zasadzie superficies solo cedit (art. 48 k.c.) prawodawca wydzielił z własności gruntu i „przydzielił" działkowcowi, który je uczynił. Jest to jednak własność z w i a z a n a

9 Takie wątpliwości mógł m.in. wywoływać art. 14 ust. 2 stanowiący, że: „Na wniosek osoby wymienionej w ust. 1, Polski Związek Działkowców ustanawia na jej rzecz prawo użytkowania działki - w rozumieniu Kodeksu cywilnego - w drodze umowy cywilnoprawnej zawartej w formie aktu notarialnego, jeżeli grunty wchodzące w skład rodzinnego ogrodu działkowego znajdują się w użytkowaniu wieczystym Polskiego Związku Działkowców lub stanowią jego własność". Zagadnienie, wobec jego obecnie już tylko historycznego znaczenia, nie będzie rozwijane, chociaż istnieją również inne „punkty zaczepienia” dla wątpliwości co do prawnorzeczowej natury prawa działkowca do działki (do gruntu) w ustawie z 2005 r. 
z dzierżawą gruntu ${ }^{10}$. Trwa więc tylko w łączności z tym prawem i tylko dopóty, dopóki służy ono działkowcowi. Ma więc ewidentnie czasowy charakter. Gdy wygasa dzierżawa gruntu, gaśnie również odrębna od niego własność nasadzeń i urządzeń.

Inter vivos działkowiec może swym prawem (dość) swobodnie dysponować. Chodzi zarówno o dzierżawę gruntu, jak i związaną z nią własność. W aktualnym stanie prawnym stanowi o tym wprost art. 41 ust. 1 (ustawy z 2013 r.). Umowa przeniesienia praw do działki wymaga zachowania formy pisemnej z podpisami notarialnie poświadczonymi. Jednak jej skuteczność uzależniona została od zatwierdzenia przez stowarzyszenie ogrodowe (art. 41 ust. 2), co można traktować jako rozwiązanie anachroniczne w dzisiejszych realiach społecznych i przede wszystkim gospodarczych ${ }^{11}$.

Pod rządami ustawy z 2005 r. dysponowanie prawem do gruntu (jeśli traktować je jako prawnorzeczowe jego użytkowanie) było z natury rzeczy wykluczone (art. 254 k.c.). Wprawdzie ustawa milczeniem pomijała związane z nim prawo własności nasadzeń, urządzeń i obiektów, jednak jako prawo związane, również ono nie mogło podlegać dyspozycji działkowca (o ile ewentualnie nie odłączył tych części składowych od gruntu).

Mortis causa, o czym szerzej w dalszym ciagu, rzeczy mają się inaczej. W tym miejscu warto już jednak zasygnalizować, że brak możliwości dysponowania mortis causa dzierżawą działki nie nasuwa wątpliwości konstytucyjnych. System prawa polskiego zna wiele podobnych „ograniczeń”. Również one nigdy nie były kwestionowane ${ }^{12}$. Istota praw obligacyjnych polega przecież na tym, że wiążą one jedynie inter partes. Mogą one zatem zgasnać wtedy, gdy „gaśnie” strona. Ich dziedziczność nie jest przecież konstytucyjnie zagwarantowana. Inaczej musi być natomiast ocenione pozbawienie możliwości rozporządzania, na wypadek śmierci, własnością nasadzeń i urządzeń. Tu pojawiaja się już istotne zastrzeżenia pozwalające zasadnie formułować zarzut niezgodności z Konstytucją RP z 1997 r. Przecież jako fundamentalną zasadę artykułuje ona ochronę własności mortis causa, czyli ochronę dziedziczenia ${ }^{13}$.

\section{ODRĘBNE REGULY „DZIEDZICZENIA” OGRODU}

„Dziedziczenie” rodzinnych ogrodów działkowych odbywa się na zasadach szczególnych, jednostkowo i specjalnie w tym celu skonstruowanych przez prawodawcę poza Kodeksem cywilnym. Ponieważ do „sukcesji” działki dochodzi

10 Zob. tak w judykaturze sądów powszechnych np.: wyrok SO w Szczecinie z 24 maja 2016 r., II Ca 1543/15, Legalis nr 2184001; postanowienia SO w Szczecinie: z 31 maja 2016 r., II Ca 1115/14, Legalis nr 2183933; z 20 września 2018 r., II Ca 149/18, Legalis nr 2181783.

11 Analogiczne „zabezpieczenia” ograniczające zbywalność „lokalu własnościowego” w spółdzielni dawno odeszły do lamusa.

12 Zob. np. wstapienie w stosunek najmu po zmarłym najemcy (art. 691 k.c.).

13 Wyrok TK z 25 lipca 2013 r., P 56/11 z glosą Justyńskiego (2019a). Zob. też Banaszak (2012): 167, teza 3 do art. 21. 
nie tylko poza prawem spadkowym, ale przede wszystkim z pominięciem jego reguł, nie można nawet mówić o „dziedziczeniu” w prawnym rozumieniu tego terminu. Lepsze, chociaż również nieidealne, jest używane przez ustawodawcę określenie „wstapienie w prawo do działki”.

Od 2013 r. kwestia wstapienia w prawo do działki regulowana jest w ustawie o rodzinnych ogrodach działkowych ${ }^{14}$. Wtedy gdy orzekał Sąd Najwyższy, obowiązywała jeszcze regulacja z 2005 r. Wspólne i charakterystyczne dla obu aktów prawnych było p o z b a w i e n i e działkowca wpływu na los ogródka mortis causa. „Dziedziczenie” w obu przywołanych ustawach polega na przejściu „dzierżawy” ogrodu, a wraz z nią własności nasadzeń, obiektów i urządzeń na wskazane w nich osoby bliskie niezależnie od woli zmarłego. Oczywiście istnieją pewne, dość istotne różnice pomiędzy obydwiema regulacjami.

W świetle ustawy z 2005 r. pewną nieścisłościa, a przynajmniej uproszczeniem, byłoby nawet mówienie o „wstapieniu w prawo” do działki po zmarłym bliskim. Prawo do działki wygasało bowiem wraz ze śmiercią działkowca. Formalnie chodziło jedynie o pojawiające się w tym momencie „pierwszeństwo w przydziale działki w razie śmierci działkowca”. Miały je „osoby bliskie użytkujące z nim wspólnie działkę" (art. 31 ust. 4 ustawy). Jeśli kilka z nich złożyło wniosek, Zarząd Ogrodów (PZD) decydował o przydziale na rzecz jednej z nich (art. 31 ust. 4 ustawy).

Ustawa z 2005 r. wprost nie wskazywała, co dzieje się z odrębną własnością nasadzeń, urządzeń i obiektów wykonanych lub nabytych przez użytkownika działki. Otwierała w ten sposób szerokie pole do rozmaitych kontrowersji ${ }^{15}$. O ile raczej nie było większych wątpliwości co do tego, że własność, jako związana z prawem do działki, wygasa, gdy wygasa użytkowanie działki, o tyle istnienie ewentualnych roszczeń związanych z ekwiwalentem za utraconą własność było w praktyce bardzo różnie oceniane.

W 2013 r. prawodawca dokonał wielu istotnych zmian. Przede wszystkim jednak, regulując materię ogrodów działkowych w nowej ustawie, metody administracyjne typowe dla tzw. realnego socjalizmu zastapił (nawet jeśli niezbyt konsekwentnie) zdecydowanie bardziej dopasowanymi do nowej rzeczywistości społecznej metodami cywilistycznymi. Usunięta została arbitralność zarządu ogrodów wyrażajacca się w d e c y d o w a n i u o pr z y d z i a l e działki. Ustapiła ona miejsca prawokształtującemu o śs w i a d c z e n i u w o 1 i bliskiego. Sprecyzowany został krag uprawnionych oraz wprowadzona kontrola sądowa. Na plan pierwszy jako wstępujący w prawo działkowca wysunięty został współmałżonek zmarłego. Jego sytuacja jest istotnie różnicowana przez prawodawcę. Jeśli był wraz ze zmarłym „współuprawnionym działkowcem”, w prawo wstępuje automatycznie. Jeśli zaś nie był, może w terminie 6 miesięcy złożyć (kształtujące) oświadczenie woli (art. 38 ust. 2). Gdyby tego nie uczynił, prawo do złożenia oświadczenia „przechodzi” na innych bliskich

14 T.jedn.: Dz. U. 2017, poz. 2176.

15 Zob. orzeczenia przywołane w przyp. 10. 
zmarłego działkowca (art. 38 ust. 2); a jeśli będzie ich więcej, o przyznaniu działki jednemu z nich zadecyduje sąd (art. 38 ust. 3).

Gwoli ścisłości, w przypadku innych niż współmałżonek bliskich nie można raczej mówić o „wstapieniu w prawo do działki służące zmarłemu”. Skoro stosownie do treści art. 38 ust. 2 prawo zmarłego wygasa, jeśli małżonek nie skorzysta ze swego uprawnienia. W tym momencie ewidentnie przerwana zostaje łączność pomiędzy tym prawem (które wygasło), a prawem innych bliskich zmarłego, którzy nabywają „roszczenie o ustanowienie prawa do działki” (art. 38 ust. 1). Trzeba jednak dodać, że prawodawca nie jest tu przesadnie konsekwentny, gdyż jednocześnie stanowi o roszczeniu o ustanowienie prawa do działki „p o z m a r ł y m”. Skoro jednak prawo to wygasło, to nie może być „po zmarłym”. Z kolei w innych przepisach mowa jest już tylko o „roszczeniu o ustanowienie prawa do działki”. Wymagałoby to jednak większej staranności legislacyjnej.

Zarówno w świetle ustawy z 2005 r., jak i regulacji z 2013 r. „nowy” działkowiec obok samej d z i e r ż a w y ogrodu nabywa też związane z nia, odrębne od gruntu, p r a w o w ł a s n o ś c i nasadzeń, urządzeń i obiektów wzniesionych przez zmarłego działkowca.

I tu trzeba dojść do, być może zaskakującej, ale jednak jedynej możliwej konkluzji. Otóż, ani prawo dzierżawy ogrodu (mimo że majątkowe przecież), ani odrębna własność nasadzeń, urządzeń i obiektów (bez wątpienia również majątkowe) nie wchodzą w skład spadku. Stosownie do treści art. 922 § 2 k.c. do spadku nie należą bowiem prawa i obowiązki majątkowe zmarłego, „które z chwilą jego śmierci przechodzą na oznaczone osoby niezależnie od tego, czy są one spadkobiercami" ${ }^{16}$. Tak właśnie bez wątpienia jest w przypadku „dwuskładnikowego” prawa działkowca do działki. Całość (tj. dzierżawa działki oraz odrębna własność inwestycji) przechodzi na wskazanych w ustawie bliskich niezależnie od tego, czy są oni (czy nie) spadkobiercami oraz również niezależnie od woli zmarłego. Co więcej, oba prawa nie wchodzą też do substratu zachowku. Nie będą więc podstawą jego obliczenia.

Twierdzenie o niepowiększaniu masy spadku na ogół nie budzi oporów i jest akceptowane. Zgoła inaczej jest ze sprawą druga. Problem zaliczania prawa do działki do substratu zachowku był w judykaturze różnie rozwiąywany, co w efekcie generowało chaos ${ }^{17}$.

Pokusie „zabezpieczenia” prawa najbliższych krewnych uprawnionych do zachowku uległ również Sąd Najwyższy. W przywołanym wyroku z 14 marca 2018 r. Sąd uznał, że odrębna własność nasadzeń, urządzeń i wzniesionych obiektów podlega zaliczeniu do substratu zachowku. Nietrafnie.

Ta właśnie sprawa, jako szczególnie skomplikowana i niejasna, wymaga zatem uwagi i starannego rozważenia.

${ }^{16}$ Obszerną analizę takich przypadków zawiera monografia Księżaka (2010). Zob. też Piątowski, Witczak, Kawałko (2009): 75-95.

17 Zob. przyp. 10. 


\section{WSTAॄPIENIE W PRAWO DO DZIALKI A ZASADY OBLICZANIA ZACHOWKU}

Jak powszechnie wiadomo, w prawie polskim, podobnie jak w wielu innych porządkach europejskich odwołujacych się do instytucji zachowku, zachowekmajacy przecież chronić moralnie szczególnie u zasadnione in teresy rodzin y - nawet wbrew woli spadkodawcy - obliczany jest w sposób szczególny. Mianowicie nie na podstawie tego, co zmarły faktycznie pozostawił (masa spadku), ale z uwzględnieniem mechanizmu korekty ochronnej (art. 993 k.c. i n.). Ma ona na celu wykluczenie pokrzywdzenia najbliższych, do którego może dojść w wyniku celowych i nieetycznych działań spadkodawcy ${ }^{18}$. Z tego właśnie powodu do substratu zachowku doliczane sa p o d a r o w a n e przedmioty majątkowe, które faktycznie w skład spadku już nie wchodza, ale - aby chronić rodzinę - traktowane sa tak, jakby darowizny nie były uczynione ${ }^{19}$.

Podobnie, jeśli testator uczynił z a p i s y (obciążające przecież spadek i de facto umniejszajace go), sa one traktowane tak, jakby w testamencie stosownych postanowień nie było.

Chodzi bowiem o to, aby spadkodawca z pomocą zapisów i darowizn nie mógł osiagnąc rezultatu faktycznego wydziedziczenia. Prawodawca polski, o czym nie trzeba nikogo przekonywać, udział rodziny w spadku traktuje bowiem jako obowiązkowy. Na jego odjęcie (wydziedziczenie) godzi się jedynie w wyjątkowych przypadkach (wyraźnie w ustawie wskazanych, art. 1008 k.c.) ${ }^{20}$. Nie akceptuje więc także sytuacji, w których spadkodawca efekt taki osiaga „drogą okrężną" (odwołując się do darowizn lub zapisów).

W tym kontekście nie dziwi specjalnie, że Sąd Najwyższy nie oparł się pokusie, aby substrat zachowku powiększyć przynajmniej o wartość nasadzeń, urządzeń i inwestycji poczynionych przez działkowca. Czyli służącej mu, odrębnej od gruntu własności. Przy tym nie może być wątpliwości, że drugi element” tandemu” „dzierżawa ogrodu” (prawo do gruntu o obligacyjnym jedynie charakterze) ani do spadku, ani do substratu zachowku nie wchodzi. Z woli prawodawcy wygasa ona przecież wraz ze śmiercią działkowca. Jedynie na zasadzie wyjątku (!) może dojść do wstapienia w to prawo przez osoby bliskie. Wtedy „dzierżawa” wprawdzie nie wygaśnie, ale i tak nie stanowi części spadku.

Odrębna od gruntu własność nasadzeń, urządzeń i inwestycji uzasadnia, prima facie, odmienną ocenę. Dominium to przecież konstytucyjnie chronione,

\footnotetext{
18 Skowrońska-Bocian (2018): 179; Piątowski (2002): 228, nb. 445.

${ }^{19}$ Szerzej a temat substratu zachowku zob. np. Kordasiewicz (2009): 869-878. Zob. też Borysiak (2013): 41-53.

${ }^{20} \mathrm{~W}$ piśmiennictwie zagranicznym zakaz taki poddawany jest już od dość dawna krytyce związanej ze zmianami społecznymi powodującymi konieczność redefinicji solidaryzmu rodzinnego. W Niemczech proponowane jest m.in. pełne uwolnienie wydziedziczenia i pozostawienie go swobodzie woli spadkodawcy. Zob. Diwell (2007): 187 n.; Martiny (2007): 196, 197. Zob. też na tle prawa polskiego Załucki (2010): $455 \mathrm{n}$.
} 
najsilniejsze prawo rzeczowe. Wbrew pozorom także w tym przypadku nie byłaby to ocena właściwa. Oderwana od gruntu własność (,tego co na nim”) stanowi wyjątek od zasady superficies solo cedit i jest prawem $\mathrm{z}$ w i a $\mathrm{z}$ a $\mathrm{n}$ y $\mathrm{m}$ z „dzierżawa” ogrodu. W konsekwencji wraz z nią wygasa albo też razem przechodzi na inne osoby. Skoro więc „dzierżawa” nie należy do masy spadkowej, nie inaczej jest ze związana z nią odrębną własnością.

Z kolei zaliczenie odrębnej własności (nasadzeń, obiektów i urządzeń) do substratu zachowku mogłoby nastapić na podstawie przywołanego juź art. 993 k.c. nakazującego „ochronną korektę”. Aby tak było, „sukcesja” odrębnej własności musiałaby być pojmowana w kategoriach zapisu albo darowizny. Ze względu na oczywisty brak miejsca na arbitralność spadkodawcy byłby to pomysł iście karkołomny. Wola spadkodawcy została tu konsekwentnie wyeliminowana i zastapiona konstrukcją ustawowa, na co nie ma on najmniejszego wpływu. Ratio legis zaś art. 933 k.c. nie wyraża się natomiast $\mathrm{w}$ ochronie przed samym prawodawca.

Dlatego konkluzja, że skoro działka wraz z nasadzeniami, obiektami i urządzeniami „przechodzi” na inne osoby bez udziału woli spadkodawcy, to brak miejsca na „ochronną korektę”, a w rezultacie powiększenie substratu zachowku, nie powinien budzić wątpliwości ${ }^{21}$.

\section{ROSZCZENIE SPADKOBIERCÓW Z TYTUŁU NASADZEŃ PO WYGAŚNIĘCIU DZIERŻAWY DZIAŁKI}

Przesądzenie tego, że prawo dzierżawy działki, a także związane z nią prawo własności poczynionych na niej przez zmarłego działkowca inwestycji (nasadzeń, urządzeń, altan) nie wchodzą do spadku ani nie stanowią podstawy obliczenia zachowku (czyli jego substratu), to jeszcze nie wszystko. Oprócz tego pojawia się istotne pytanie o ewentualne roszczenia spadkobierców powstające po wygaśnięciu (i z powodu wygaśnięcia) prawa do działki. Niewykluczone przecież, że żadna z osób bliskich (wskazanych w ustawie jako uprawnione do „wstapienia w prawa zmarłego" działkowca) oświadczenia nie złoży, w rezultacie czego prawo do działki wygaśnie.

Chodzi oczywiście o ekwiwalent utraconego prawa własności nasadzeń i urządzeń poczynionych przez działkowca. A więc o to, czy spadkobiercom służy roszczenie o zwrot ich wartości, a także pytanie o to, kto ewentualnie miałby być jego adresatem (właściciel gruntu, czy zarząd ogrodów).

${ }^{21}$ Odmiennie, nietrafnie Księżak (2010): 305, 85. Wprawdzie analizując różne prawa przechodzące na następców zmarłego poza prawem spadkowym, ich ewentualne zaliczenie do substratu zachowku autor słusznie uzależnia od tego, czy wola spadkodawcy (jak przy darowiźnie albo zapisie) ma znaczenie czy też nie, następnie jednak niekonsekwentnie twierdzi, że własność obiektów, urządzeń i nasadzeń (inaczej niż sama „dzierżawa” ogrodu) zaliczeniu podlega. Można sądzić, że autor zdanie zmienił, gdyż nie powtarza tej koncepcji w późniejszych opracowaniach (zob. komentarz do art. 993 k.c.: Księżak 2019). 
Problem z dość oczywistych powodów nie dotyczy samej dzierżawy gruntu. Ta - z woli prawodawcy - gaśnie. A skoro gaśnie, to - jako prawo obligacyjne bez ekwiwalentu ${ }^{22}$.

Natomiast w aktualnym stanie prawnym, tj. w świetle uregulowań ustawy z 2013 r., nie może być raczej wątpliwości, że po wygaśnięciu prawa dzierżawy działki w związku ze śmiercią działkowca spadkobiercom zmarłego, co do zasady, służy roszczenie o zapłatę za utraconą własność nasadzeń i urządzeń. Warto jednak nieco uwagi poświęcić zarówno jego zakresowi, jak i, co mogłoby - niesłusznie - wydać się zbędne, adresatowi roszczenia.

Otóż, roszczenie nie jest pełne. Nie obejmuje mianowicie całej wartości inwestycji poczynionych przez zmarłego działkowca, a jedynie te, które „uczyniono zgodnie z prawem”. Wyraźnie przesądza o tym przepis art. 42 ust. 1 ustawy.

To właśnie rozwiązanie musi budzić wątpliwości konstytucyjne. Łatwo bowiem dostrzec, że dochodzi tu do swoistego „wywłaszczenia” zmarłego z części jego majątku. Nieważne, że chodzi o inwestycje uczynione niezgodnie z przepisami. Zmarły nie może już przecież niczego od działki odłączyć. Prawo odłączenia nie służy również jego spadkobiercom. Utrata tej części majątku nie da się $\mathrm{w}$ żadnym razie pogodzić z konstytucyjna ochroną własności (inter vivos) oraz mortis causa (ochrona dziedziczenia; art. 21 oraz 64 Konstytucja RP). De lege ferenda spadkobiercom należałoby przyznać przynajmniej prawo odłączenia poczynionych inwestycji (nasadzeń, urządzeń, altan) od gruntu. Ewentualne wyposażenie spadkobierców w roszczenie pieniężne wymagałoby starannego wyważenia interesów obu stron, w tym uwzględnienia faktu niezgodnego z prawem (np. wzniesienia altany i ewentualnych możliwości legalizacji).

Skoro pojawia się roszczenie majątkowe, to konsekwentnie przyjąć należy, że zarówno wchodzi ono do spadku po zmarłym działkowcu (jednak nie można zapominać, że tylko dlatego, iż nikt w prawa te nie wstapił) oraz że powiększa ono substrat zachowku.

\section{ADRESAT ROSZCZENIA SPADKOBIERCÓW}

Jak już wspomniano, sprawa adresata roszczenia spadkobierców zmarłego działkowca z tytułu własności, która wygasła, nie jest oczywista. Mamy tu bowiem do czynienia z jednej strony z właścicielem gruntu (którym jest Państwo/ samorząd terytorialny, a jedynie czasem Ogrody działkowe - PZD), z drugiej zaś - z Ogrodami działkowymi (PZD) jako użytkownikiem gruntu. Ten drugi podmiot zarządza ogrodami, ustala regulaminy korzystania, pobiera ewentualne opłaty, a w szczególności przydziela działki. To on w istocie prowadzi ogród i z niego korzysta.

${ }^{22}$ Wprawdzie w ustawie z 2005 r. prawo działkowca mogło być traktowane jako prawnorzeczowe, jednak nawet takie podejście nie zmieniałoby optyki. Użytkowanie (ustanowione na rzecz osoby fizycznej) nie jest przecież dziedziczne i wygasa najpóźniej ze śmiercią uprawnionego (art. 260 k.c.). 
Po wygaśnięciu odrębnej od gruntu własności inwestycji poczynionych przez działkowca (nasadzeń, urządzeń, altan) prawo to konsoliduje się jednak w rękach właściciela gruntu ${ }^{23}$. A zatem powraca ono do gruntu zgodnie z zasadą superficies solo cedit. Obserwacja ta może dawać asumpt do uznania, że to właściciel gruntu jest właściwym adresatem roszczenia spadkobierców.

Wniosek taki nie byłby słuszny. Nie uwzględnia on w szczególności „piętrowej konstrukcji” prawa działkowca. Mianowicie właściciel (Państwo/ samorząd terytorialny) oddał grunt do używania Ogrodom działkowym, aby te z kolei oddawały działki działkowcom. Po wygaśnięciu prawa działkowca, wobec jego śmierci, w istocie działka wraca nie do właściciela, ale właśnie do użytkownika gruntu i dysponenta działek, czyli do Ogrodów. To Ogrody (a ściślej: ich Zarząd) przydzielają działkę kolejnej osobie. Odrębna dotąd własność nasadzeń, urządzeń i obiektów wprawdzie „formalnie” konsoliduje się z prawem właściciela gruntu, jednak de facto również ona „wraca” do jego użytkownika, czyli do Ogrodów działkowych. To one przecież użytkują grunt „ze wszystkim co na nim" i tym swoim użytkowaniem dysponują (wraz z nasadzeniami, urządzeniami, altanami). Prawo użytkowania gruntu przez Ogrody działkowe rozciaga się niewątpliwie, zgodnie z zasadą superficies solo cedit, także na wszystko, co zostało z nim w sposób trwały połączone.

W rezultacie trzeba zatem dojść do wniosku, że to właśnie Ogrody działkowe (stowarzyszenia działkowe) są właściwym adresatem roszczeń spadkobierców. To przedmiot, z którego właśnie one korzystaja, zyskał na wartości. To jedynie one mogą bez problemów ten „wzrost wartości” rozliczyć na bieżąco, przydzielając bardziej wartościową działkę kolejnemu („nowemu”) działkowcowi.

Do takiego wniosku musi także prowadzić obserwacja, że prawodawca jedynie w jednym przypadku, a mianowicie w razie likwidacji ogrodu, jako adresata roszczeń odszkodowawczych działkowca wskazał podmiot likwidujący, czyli de facto właściciela gruntu (zob. art. 22 ustawy). Regulując zaś pozostałe sytuacje, w których dochodzi do wygaśnięcia prawa do działki, wprawdzie nie wprost, ale jednak w sposób stosunkowo wyraźny wskazał stowarzyszenia ogrodowe jako adresata roszczeń odszkodowawczych. W art. 42 ust. 4 ustawy mowa przecież o stowarzyszeniu ogrodowym, które „w braku porozumienia [co do warunków zapłaty i wysokości wynagrodzenia - T.J.] może w trybie procesu żądać sprzedaży nasadzeń, urządzeń i obiektów w drodze licytacji”.

Tylko taka konstrukcja (a więc postrzeganie w ogrodach działkowych adresata roszczeń spadkobierców zmarłego działkowca) jest zarazem i słuszna, i sprawiedliwa, a jednocześnie konstrukcyjnie poprawna.

Oczywiście nie oznacza to, że pomiędzy Ogrodami działkowymi jako użytkownikiem a właścicielem gruntu nie może dojść do rozliczenia, skoro formalnie to przecież Państwo/ samorząd terytorialny nabywa własność przyłączonych inwestycji. Oczywiście tak. Czas na rozliczenie z właścicielem nadejdzie jednak wtedy, gdy dojdzie do likwidacji Ogrodu. Właśnie wtedy rozliczony zostanie ewentualny wzrost wartości gruntu i nakłady.

${ }^{23} \mathrm{Na}$ temat konsolidacji praw rzeczowych zob. Justyński (1997): 30 n. 


\section{SPOSTRZEŻENIA DE LEGE FERENDA}

Pożądanym dopełnieniem wyraźnego renesansu prawa spadkowego w Polsce będzie zmiana regulacji prawnej dotyczącej „sukcesji” ogrodów działkowych. Obecna jest tworem niespójnym, ciagle jeszcze zawieszonym pomiędzy systemem nakazowo rozdzielczym (charakterystycznym dla czasów tzw. realnego socjalizmu) a cywilistyczną własnością i jej poszanowaniem (fundamentalnym w aktualnych realiach ustrojowych). Zarysowane problemy związane z „dziedziczeniem” ogrodów działkowych wynikają w istocie z tego, że prawodawca zbudował obecne rozwiązanie prawne z wyraźnie niepasujących do siebie elementów obu przeciwstawnych koncepcji. Nie chodzi już wprawdzie o czysty „model administracyjny” (związany z rozdzielnictwem dóbr i przywilejów), nie jest to jednak także własność (lub inne zbywalne i dziedziczne prawo) ze wszystkimi tego konsekwencjami.

Czas już przesądzić, że chodzi o pełną (podlegającą dziedziczeniu) własność ogrodu i wszystkiego „co na nim” (lub inne w pełni zbywalne i dziedziczne prawo), i zastapić nim obecną „limitowaną konstrukcję” (,z pewnymi jedynie elementami dziedziczenia i ograniczoną zbywalnością), przysparzającą kłopotów interpretacyjnych sądom. Kroku tego nie należy się obawiać. Podobna operacja na prawie spółdzielczym dokonała się już dawno i nie zaszkodziła istocie rzeczy.

Można zastanawiać się nad tym, czy dziedziczenie powinno następować na ogólnych zasadach prawa spadkowego, czy też być raczej wyłączone spod tego reżimu, co wydaje się mieć zalety. Niezależnie od rozstrzygnięcia tej kwestii słuszne wydaje się natomiast wyposażenie działkowca w prawo dysponowania ogrodem mortis causa. Oczywiście to ostatnie nie wyklucza zastosowania jakiegoś mechanizmu przeciwdziałającego rozdrobnieniu substancji działkowej. Niewłaściwe, zresztą z wielu powodów, jest różnicowanie charakteru prawnego uprawnień małżonka i innych bliskich (wstapienie w prawo zmarłego, nabycie roszczenia o ustanowienie).

Należałoby także wprost wskazać adresata roszczeń spadkobierców zmarłego działkowca na wypadek wygaśnięcia prawa do działki. A taką ewentualność trzeba jednak uwzględnić, zważywszy chociażby na to, że prawo do działki powinno być jednak aktywnie wykonywane. Obecnie możliwe jest wprawdzie wyinterpretowanie adresata roszczenia w drodze wykładni, ponieważ jednak chodzi o ustawę skierowaną do szerokich rzesz działkowców, to właśnie oni, nie zaś wyspecjalizowani prawnicy, nie powinni mieć wątpliwości w tym zakresie.

Banaszak, B. (2012). Konstytucja Rzeczpospolitej Polskiej. Komentarz. Warszawa.

Borysiak, W. (2013). Prawa i obowiązki przechodzące na poszczególne osoby niezależnie od tego, czy są one spadkobiercami, [w:] K. Osajda (red.), Kodeks cywilny. Komentarz. Tom 3: Spadki. Warszawa: 41-53.

Bucholz, P. (2007). Pflichtteilsrecht als Naturrecht? [w:] A. Röthel (Hrsg.), Reformfragen des Pflichtteilsrechts. Symposium 30.11.-2.12.2006 in Salzau. Köln-Berlin-München: 119-133.

Diwell, L. (2007). Reformfragen im Erb- und Pflichtteilsrecht. Spielräume aus Sicht des Bundesministerium der Justiz, [w:] A. Röthel (red.), Reformfragen des Pflichtteilsrechts. Symposium 30.11.-2.12.2006 in Salzau. Köln-Berlin-München: 185-193. 
Jasiakiewicz, T. (2017). Glosa do wyroku SN z dnia 16 czerwca 2016 r., V CSK 625/15. Orzecznictwo Sądów Polskich 61(9): 135-141.

Jasiakiewicz, T. (2018). Glosa do uchwały SN z dnia 17 marca 2017 r., III CZP 110/16. Orzecznictwo Sądów Polskich 62(9): 6-11.

Justyński, T. (1997). Konfuzja i konsolidacja w polskim prawie cywilnym. Przegląd Sądowy 10: $30-41$.

Justyński, T. (2000). Nadużycie prawa w polskim prawie cywilnym. Kraków.

Justyński, T. (2014). Glosa do wyroku SN z dnia 13 grudnia 2013 r., III CZP 79/13. Orzecznictwo Sądów Polskich 58(10): 1273-1278.

Justyński, T. (2015). Uwagi w sprawie prawnej dopuszczalności zawierania umów darowizny mortis causa. Przegląd Sądowy 24(4): 7-16.

Justyński, T. (2017). Glosa do wyroku SN z dnia 16 czerwca 2016 r., V CSK 625/15. Orzecznictwo Sądów Polskich 61(2): 105-112.

Justyński, T. (2018a). Uprzywilejowana wysokość zachowku w polskim prawie spadkowym (w świetle art. 991 k.c.) na tle współczesnych tendencji rozwojowych, [w:] J.M. Łukasiewicz, M. Załucki (red.), Prawo rodzinne i spadkowe wobec współczesnych zjawisk technologicznych i społecznych. Toruń: 331-352.

Justyński, T. (2018b). Glosa do uchwały SN z dnia 17. marca 2017 r., III CZP 110/16. Orzecznictwo Sądów Polskich 62(11): 3-8.

Justyński, T. (2019a). Zrzeczenie się zachowku. Glosa do Wyroku Trybunału Konstytucyjnego z dnia 25 lipca 2013 r., P 56/11. Orzecznictwo Sądów Polskich 63(3): 3-13.

Justyński, T. (2019b). Zezwolenie na rodzicielską czynność zarządu majątkiem dziecka, glosa do uchwały SN z 15 lutego 2019 r., III CZP 85/18. Krakowski Przegląd Notarialny 4(4): 139-147.

Justyński, T. (2019c). Nadużycie prawa a terminy zawite do odrzucenia spadku oraz uchylenia się od skutków prawnych niezłożenia oświadczenia, glosa do uchwała SN z 15 marca 2018 r., III CZP 110/17. Orzecznictwo Sądów Polskich 63(10): 19-23.

Justyński, T. (2020a). Koniec biegu terminu zawitego do przyjęcia lub odrzucenia spadku a konstrukcja nadużycia prawa (art. 5 k.c.), glosa do postanowienia SN z 12 kwietnia 2018 r., II CSK 485/17. Orzecznictwo Sądów Polskich 64(1): 6-12.

Justyński, T. (2020b). Rodzicielskie oświadczenie o przyjęciu lub odrzuceniu spadku a termin zawity z art. 1015 k.c., glosa do uchwały SN z dnia 22 maja 2018 r., III CZP 102/17. Orzecznictwo Sądów Polskich 64(3): 21-29.

Justyński, T. (2020c), „Ogródek działkowy w spadku”. Rzeczpospolitej z 10 marca 2020 r. (dodatek tygodniowy „Rzecz o prawie”): D3.

Justyński, T. (2020d). Nadużycie prawa do żądania zachowku (art. 5 k.c.) i „dziedziczenie” rodzinnego ogródka działkowego, glosa do Wyrok SN z dnia 14 marca 2018 r., II CSK 276/17. Krakowski Przegląd Notarialny 5(1): 67-75.

Kordasiewicz, B. (2009). Substrat zachowku, [w:] Z. Radwański (red.), System prawa prywatnego. Prawo spadkowe. Tom 10. Warszawa: 869-878.

Księżak, P. (2010). Zachowek w polskim prawie spadkowym. Warszawa.

Księżak, P. (2015). Glosa do wyroku SN z dnia 13 grudnia 2013 r., III CZP 79/13. Państwo i Prawo 70(10): 123-128.

Księżak, P. (2016). Glosa do uchwały SN z dnia 16 października 2014 r., III CZP 70/14. Przegląd Sądowy 25(1): 119-123.

Księżak, P. (2019). Art. 993 k.c., [w:] K. Osajda (red.), Kodeks cywilny. Komentarz. Spadki. Wyd. 1. Legalis.

Martiny, D. (2007). Zur Reform des Pflichtteilsrecht, [w:] A.Röthel (Hrsg.), Reformfragen des Pflichtteilsrechts. Symposium 30.11. - 2.12.2006 in Salzau. Köln-Berlin-München: 195-202.

Piątowski, J.S. (2002). Prawo spadkowe. Zarys wykładu. Warszawa.

Piątowski, J.S., Witczak, H., Kawałko, A. (2009). Wyłączenie praw i obowiązków przechodzących na oznaczone osoby niezależnie od ich przymiotu spadkobierców, [w:] Z. Radwański (red.), System prawa prywatnego. Prawo spadkowe. Tom 10. Warszawa: 75-95.

Pyziak-Szafnicka, M. (2007). Nadużycie prawa podmiotowego, [w:] Z. Radwański (red.), System prawa prywatnego. Tom 1: Prawo cywilne - część ogólna. Warszawa: 771-827.

Skowrońska-Bocian, E. (2018). Prawo spadkowe. Warszawa.

Załucki, M. (2010). Wydziedziczenie w prawie polskim na tle porównawczym. Warszawa. 


\section{THE ‘SUCCESSION’ OF FAMILY ALLOTMENT GARDENS: REMARKS DE LEGE LATA AND DE LEGE FERENDA}

\section{Sum mary}

Recently courts in Poland have been increasingly often confronted with the very interesting and legally equally complex problem of the 'succession' of family allotment gardens (RODs). It appears that in relation to this asset important succession problems arise, having both a theoretical nature and great practical significance - namely an answer to two fundamental questions, as well as a few more precise ones: firstly, whether an allotment (including varieties and facilities) is a part of an estate, and, therefore, whether it is inherited in accordance with general principles, like any other asset; and secondly, whether a family allotment garden increases the basis for the calculation of legitim (i.e. legitim fund) for persons not mentioned in the last will and for that reason not inheriting. It appears that the answer to these questions causes great difficulties for the judiciary. Although the first question generally does not cause insurmountable interpretative problems (the issue was relatively clearly, although not directly, prejudged in the Act on family allotment gardens of 2005, and subsequently of 2013), the second question poses a real challenge even for a lawyer specialising in succession. The article deals with both questions as well as many others which are their consequences. Not only are separate rules of the 'succession' of family allotment gardens presented (which should not be understood as a succession based on inheritance law), but also the claims of the heirs of the deceased person regarding the revocation of the right to the allotment and particularly the addressee of these claims. This latter problem is not obvious in the light of the current legal rules. The author also draws conclusions de lege ferenda. He proposes among other things - prescribing the inheritance and transferability of family allotment gardens.

Keywords: succession law; inheritance; family allotment gardens; inheritance of allotment gardens 
